\section{K PROBLEMATICE NÁKLADOVÉ EKVITY FUNKCIONALIT: JE E-HEALTH OPRAVDU V NEVÝHODĚ?}

\section{Miroslav Prádka}

\section{Anotace}

$K$ evergreenům kritiky funkcionalit e-Health patří $\mathrm{i}$ jejich domnělé vyšší provozní náklady. Z pohledu způsobů úhrady provozních nákladů e-Health a non-e-Health funkcionalit je pak výrazným argumentem ekvita príslušných úhrad, a to zvláště v případě účasti veřejných finančních prostředků. Příspěvek se zabývá možnostmi posouzení nákladové ekvity u vybraných funkcionalit e-Health.

\section{Klíčová slova}

e-Health, implementace, ekvita úhrad

\section{1 Úvod}

Jednotlivé funkcionality e-Health uvažované k implementaci v souladu s Národní strategií elektronického zdravotnictví [1] (NSeZ) představují významný zdroj změn ve fungování systému zdravotnictví. Mnohdy se Ize setkat s více či méně artikulovanou kritikou způsobu zavádění e-Health, často je poukazováno na riziko možných vyšších provozních nákladů, které v konečném důsledku má nést poskytovatel zdravotní péče či plátce zdravotní péče. Nelze zastírat, že každá technologická změna, a tedy i implementace e-Health, bude znamenat určité aditivní náklady. Není však vhodné nechat se unést představou o špatné návratnosti či dokonce nevratnosti nákladů potřebné technologické změny.

\section{Vhodné paralely}

Ekonomické rozvahy ve zdravotnictví jsou rutinně prováděny při pořizování souborů př́strojové techniky či staveb. Především u stavebních objektů jsou k dispozici různé metodiky hodnotící náklady na zhotovení, provozování či vynucené úpravy staveb po dobu jejich životnosti včetně nákladů na finální odstranění stavby (např. [2]). Je zapotřebí si uvědomit, že náklady na zhotovení stavby (tedy technologického celku) jsou jen menší částí nákladů vynakládaných během cyklu uživání stavebního díla.

Životnost posuzovaného technologického celku (v uvažovaném prípadě stavby) pak bývá hodnocena z více aspektů, které jsou jednoznačně opodstatněné:

\section{- Ekonomická životnost \\ - Technická životnost \\ - Právní životnost \\ - Morální životnost}

\section{Nákladovost funkcionalit e-Health}

Pro jednoduchost lze uvést, že tak jako je nevýhodné pořídit si stavbu s nízkou pořizovací cenou, která však není energeticky šetrná, není taktéž výhodné obdobným způsobem implementovat ani jiný technologický celek. Posuzovat rentabilitu implementovaného celku pouze $z$ jeho pořizovací ceny je taktéž zcela nedostatečné.

Implementaci funkcionalit e-Health je zapotřebí hodnotit v širším kontextu jako technologickou změnu s dopady do různých oblastí prováděných činností, tedy jako komplexní proces, který musí být adekvátně vyhodnocen především s ohledem na:

- zvyšování kvality, dostupnosti a bezpečnosti poskytovaných služeb;
- potřebné zvyšování produktivity práce zdravotnického personálu;

- snižování rizik;

- facilitaci obchodních vztahů poskytovatele péče;

- zlepšení zákaznické komunikace.

Jednou z možností k provedení komplexní analýzy nákladovosti technologických celků ve zdravotnictví představují disponibilní metody HTA (Health Technology Assessment). V této souvislosti je však zapotřebí doplnit, že je nezbytné provádět vyhodnocení pomocí HTA nikoli parciálně, ale průřezově se zaměřením na hodnocení komplexních vyvolaných změn, a to u vědomí limitů některých metodik (např. QALY).

\section{$4 \mathrm{~K}$ problematice nákladové ekvity a spoluúčasti $v$ sys- tému zdravotnictví}

Nasazování funkcionalit e-Health může být vázáno na provádění výkonů vázaných na úhradu z veřejného zdravotního pojištění (např. e-Recept). Často bývá záměrem pomocí funkcionality e-Health substituovat činnost prováděnou dřive jiným způsobem a za jiných nákladů.

Zavádění e-Health by však rozhodně nemělo opodstatňovat jakékoli navyšování plnění z veřejných finančních zdrojů; naopak za podmínky provádění bilance nákladů a výnosů technologické změny (viz výše) by měla být prokazatelným způsobem potvrzena rentabilita implementovaného procesu.

V prípadě souběžného užívání e-Health a non-e-Health funkcionality by pak obdobným způsobem měla být stanovena nákladovost obou používaných variant s tím, že z pohledu plátců by tyto měly být nákladově shodné - není důvod z veřejných finančních prostředků dotovat (!) některou z disponibilních funkcionalit, pokud tyto různým způsobem realizují stejnou službu/funkci.

Vlastní dorovnání rozdílných nákladů jednotlivých funkcionalit by pak mělo být vhodným způsobem zohledněno vůči těm, kteří z vlastního rozhodnutí preferují nákladnější funkcionalitu/variantu.

Návrh způsobu dosažení nákladové ekvity:

- Spoluúčast, žádá-li konzument nákladnější variantu péče;

- Úhradový regulativ, poskytuje-li poskytovatel ze svého rozhodnutí nákladnější variantu péče.

\section{E-Recept jako modelový př́klad}

Vlastní nákladová bilance e-Receptu (e-Rp) vůči receptu předepsanému $v$ listinné podobě není doposud jednoznačně stanovena a bude možno ji upřesnit nákladovou analýzou po masovém nasazení e-Rp během dostatečně dlouhého období. Zahrnutím podstatných nákladových komponent (mj. nákladů archivace, chybovosti vydaných receptů, souvisejícího pracovního času zdravotnického pracovníka, atd.) bude možno vyjádřit nákladový rozdíl vázaný na jeden předepsaný recept ve zjištěné nákladnější formě.

\section{Závěr}

Šetrnost při financování systému zdravotnictví je jedním z klíčových parametrů jeho dlouhodobé udržitelnosti. Zavádění technologických změn vyžaduje kvalifikované posouzení vyvolaných nákladů a v případě úhrad z veřejných zdrojů i zajištění nákladové ekvity ( $v$ prípadě existence více způsobů zajištění téže služby/funkce).

Při zavádění funkcionalit e-Health (dle harmonogramu schválené NSeZ) mohou být vyvolané náklady při volbě nákladnější funkcionality kvantifikovány a dále zohledněny s cílem dosažení nákladové ekvity funkcionalit. 


\section{Literatura}

[1.] MINISTERSTVO ZDRAVOTNICTVÍ ČESKÉ REPUBLIKY. Národní strategie elektronického zdravotnictví. Verze 1.00. Praha, 2016. Licencováno pod CC BY 4.0, licenční podmínky dostupné z: http://creativecommons.org/licenses/by/4.0/.

[2.] Beránková, E. (2013). Životní cyklus staveb. FAST VŠB-TUO Ostrava, 2013. Fulltext dostupný z: http://www.tzb-info.cz/udrzba-budov/10219-zivotni-cyklus-staveb.

[3.] Přádka, M. (2013). Coniunctio oppositorum aneb o elektronickém receptu v nemocnici s certifikátem ČLK. TEMPUS MEDICORUM, No. 4, 2013, 37, ISSN 1214-7524.

\section{Kontakt}

\section{Miroslav Přádka}

Ben Labor s.r.o.

Chittussiho 1001/9

71000 Ostrava

e-mail: miroslav.pradka@seznam.cz 